\title{
The Rise of Engaged Citizenship The Evolution of Citizenship Norms among Adolescents in 21 Countries between 1999 and 2009
}

\begin{abstract}
Various authors claim that citizenship norms are changing rapidly in advanced democracies, leading to a stronger emphasis on self-expressive engagement and a decline of notions of civic duty. In this article, we compare results from two comparative surveys of adolescents: the 1999 Civic Education Study and the 2009 International Civic and Citizenship Survey (ICCS). By using latent class analysis we identify duty-based and engaged citizenship norms, both in 1999 and in 2009. As expected, the group supporting duty-based citizenship norms is clearly smaller in 2009 than in 1999, while the opposite is true for the group supporting engaged citizenship norms. In contrast to expectations, the empirical evidence also distinguishes additional normative concepts, and shows that the distribution among countries is not according to the dynamics on value change as suggested in the literature, including a decline in engaged norms in Scandinavia and Western Europe.
\end{abstract}

Keywords: citizenship norms, value change, engaged citizenship, duty-based citizenship, latent class analysis 


\section{INTRODUCTION}

Within industrially advanced societies, political and social norms and attitudes are changing rapidly, especially as young age cohorts pay more attention to self-expressive values and to the importance of individual freedom (Welzel 2013). This process of value change implies that these groups will relate differently to political systems than previous generations did. Traditional ideological cleavages are now less salient, while party membership and electoral politics are losing ground among younger age groups (Blais, Gidengil \& Nevitte 2004; Blais

\& Rubenson 2013; Klingemann 2015; Whiteley 2011). Simultaneously, however, other forms of political and civic engagement are gaining ground, and these forms of engagement are less oriented toward electoral politics, but rather to various community, voluntary and social movement oriented forms of participation (Flanagan 2013; Inglehart \& Catterberg 2002; Zukin et al. 2006). These changes do not just signal different organizational preferences, but may be the result of changing citizenship concepts (Norris 2011). More specifically various authors argue that duty-based citizenship norms are being replaced by a more engaged or critical form of citizenship, whereby especially younger age groups place more emphasis on actively helping out in their community in a non-institutionalized manner (Dalton 2008; Flanagan 2013; Norris 2011; Sloam 2013). Previous studies indeed show that this engaged form of citizenship can be identified, and that it is clearly present in at least some Western societies (Copeland 2014; Dalton 2007, 2008; Martin 2012; Raney \& Berdahl 2009; Shulman \& Levine 2012). It is assumed that especially in the Scandinavian countries, these norms will be strongly present (Dalton \& Welzel 2015).

While there seems to be a consensus in the sociological literature about the occurrence of this process of value change, opinions differ on the conceptualization of this process. Various authors use different terms to describe this newly emerging citizenship norm, including 'self-actualizing' (Bennett, 2012), 'critical' (Norris 1999, 2011), 'monitorial' 
(Schudson 1998) and 'engaged' (Dalton 2007, 2008). Although these terms highlight different aspects of citizenship norms, these studies represent a growing consensus that contemporary young people are often highly engaged within their communities, while simultaneously they de-emphasize traditional duty-based concepts of citizenship. These changes lead to the expectation that young age groups will prefer social-movement oriented forms of participation, rather than participation that is directed toward electoral politics (Torney-Purta 2001). Indeed, empirical studies demonstrate such a shift in participation repertoires (Stolle \& Hooghe 2011), but while these studies are compatible with the broader thesis of value change, they cannot be considered as a final test of these theories. If we want to test the claim that civic value patterns are changing in Western societies, it is important to investigate the trends with regard to these attitudes and values in a more direct and comparative manner.

The theoretical literature on new citizenship norms emphasizes that value change takes place across industrial democracies. Most of the available empirical studies, however, are based on cross-sectional observations that do not allow us to test the claim that engaged citizenship has become more prevalent (e.g. Dalton 2008) or they investigate over-time changes in a single country or region (e.g. Howe 2010; Oser \& Hooghe 2013). In this article, we aim to investigate in a comparative manner changes over time in citizenship norms. We do so using two large surveys among adolescents that were conducted in 1999 and 2009. Both the 1999 Civic Education Study and the 2009 International Civic and Citizenship Survey included a full battery of items on citizenship norms. This means we can compare the results for both studies for the 21 countries that participated in both data gathering efforts, and it also allows us to investigate differences between countries with regard to the prevalence of these norms. As far as we know, no other broad comparative dataset includes such a comprehensive battery on citizenship norms. Most previous studies on this topic opted for an item-based analysis of either single-item studies (e.g., Bolzendahl \& Coffé 2013) or attitudinal scales 
(e.g., Dalton 2008). The theory does not only predict support for specific scales, but rather it also assumes that actors will have very specific combinations of responses regarding what constitutes good citizenship. The theory thus predicts changes at the level of the actor and in order to adequately test the theory, this should also be our unit of analysis. We opt therefore for an actor-centered analytical technique (latent class analysis) that is explained more fully in the methods section of this article.

In the remainder of this article, we first briefly review the literature on changing citizenship norms among young age cohorts, before we present data and methods. We next ascertain the characteristics of citizenship norms in both surveys in order to investigate changes over time and to investigate differences between countries. In the concluding section, we reflect on what our findings tell us about the claim that citizenship norms are rapidly changing, especially among young age cohorts.

\section{CHANGING CITIZENSHIP NORMS}

Just over a decade ago, the prevailing mood in the literature on the civic engagement of young age groups was rather pessimistic, as authors claimed that younger age groups are less inclined to participate in political and community life (Pharr \& Putnam 2000). Other authors, however, strongly countered this line of thinking by claiming that new generations do not abandon politics, but rather that they reshape the way politics is being performed (Bennett \& Segerberg 2013; Inglehart \& Welzel 2005; Norris 2002; Zukin et al. 2006). These changes are well documented with regard to political behavior and participation, demonstrating that traditional, electoral forms of participation like voting or party membership are in decline among young age groups (Blais \& Rubenson 2013; Bolzendahl \& Coffé 2013; Fieldhouse et al. 2007), while these adolescents and young adults are much more active in non- 
institutionalized or elite-challenging forms of participation (Marien, Hooghe \& Quintelier 2010; Welzel \& Deutsch 2012).

In this literature on the development of participation patterns, a number of authors highlight that changing citizenship norms are the main driving force for this process of social change (Bennett 2012; Norris 1999, 2002; Dalton 2007, 2008; Schudson 1998). Inglehart and Welzel (2005) claim that younger age groups are more critical toward political institutions and organizations as they prefer an individualized form of engagement, that allows them to express their own individual preferences and inner convictions. According to their 'human development theory', the fact that education levels and cognitive sophistication are rising among this younger age group allows them to develop a far more individualized pattern of political preferences in comparison to previous generations. Bennett and Segerberg (2013) build on the work of Castells (2000) to argue that young age groups avoid traditional political institutions, as they prefer loose and more informal networks. As a result of the emergence of new forms of electronically mediated communication networks, an idiosyncratic network structure of interaction partners can be established. The 'critical citizen' concept (Norris, 1999, 2011) departs from the assumption that younger age cohorts no longer adopt a deferential attitude toward authorities and institutions, but instead develop a more critical attitude toward politics, while simultaneously they are staunch supporters of basic democratic values. Among these theories about the nature of political value change, Dalton (2013) offers the most explicit claims about the consequences of these changes for political engagement. He argues that evolving citizenship norms are guiding political behavior. In his argument, the structural change takes place at the level of norms and attitudes, and not at the level of behavioral patterns. Following Dalton $(2008,78)$ we define citizenship norms as 'a shared set of expectations about the citizen's role in politics.' The assumption is that these norms guide 
the behavior of citizens (John, Fieldhouse \& Liu 2011; Straughn \& Andriot 2011). As Dalton claims:

...the norms of citizenship are vital to understanding the political behavior of the American public (...) My central premise is that the social and political modernization of the United States - and other advanced industrial democracies - over the past several decades has systematically altered the distribution of citizenship norms in significant ways (Dalton 2008: 77).

The basic idea in this line of the literature is that citizenship norms held by young age groups still stress the importance of an active involvement in social life (Eliasoph 2013; Flanagan 2013). The difference with previous generations, however, is that norms now depart from different motivations. In the past, a sense of civic and moral duty often served as the guiding principle (Blais 2000). Even without an intrinsic motivation, civic engagement was simply seen as the duty of a citizen because of external pressures, the message by political elites, or simple tradition. Partly as a result of cognitive mobilization and higher education levels, this unquestioning acceptance of the duty argument, however, has become obsolete as young citizens are more critical (Bobek et al. 2009; Norris 2011). Duty-based norms are being replaced by what Dalton (2008) labels ‘engaged citizenship', i.e. an action-based form of citizenship where activism in the local community is valued for its own sake. This form of intrinsic engagement can also express itself in network and internationally oriented forms of engagement (Bennett \& Segerberg 2013). These emerging citizenship norm expect less from state institutions, as the focus is clearly on what citizens themselves can do without being dependent on state intervention. Theoretically this is congruent with the notion of lifestyle activism as it was developed in the work of Giddens (1991). 
The literature on changing citizenship norms relates to broader processes of social change. Dalton (2008: 81) argues that the rise of an engaged citizenship norm is a consequence of a post-modernization process that leads to the spread of self-expressive values (Inglehart \& Welzel 2005; Welzel 2013). These values, in turn, lead to the observation that 'engaged citizens' will be more sensitive to issues like human rights, but they will also be less deferential toward political authorities and political elites.

Despite this well-developed literature on changes in citizenship norms comparative data over time are scarce. In their reviews of the citizenship norm literature, Bennett (2012) and van Deth (2007) note that comparative empirical research on citizenship norms is limited, especially outside North America and Europe. Although the literature about the behavioral effect of changing citizenship norms relates to changes over time, it is striking to note that the empirical support that Dalton marshals for this thesis is based largely on cross-sectional observations from the United States (Dalton 2007, 2008). Beyond the U.S., engaged or critical citizenship norms have been identified in a number of cross-sectional studies, including single-country studies of Canada (Raney \& Berdahl 2009) and Australia (Martin 2012), and Dalton's (2007: 138-160) analysis of 19 established democracies. Yet, these studies do not inform us about whether engaged citizenship is actually on the rise. Given the general literature on value change and cognitive mobilization, this might be expected, especially in countries that traditionally score high on postmaterialist indicators (Inglehart 1997), but there is no conclusive evidence yet in the literature. While most studies focus on Northern and Western Europe, there is far less information available about the spread of the attitudes in other geographical regions.

The aim of the current article is to address the question of over-time change by analyzing strictly comparative data from 1999 and 2009. If value change in recent years is indeed such a 
powerful and structural process as Bennett, Dalton, Inglehart, Norris, Welzel and other authors argue, a decade should be sufficient to observe significant changes in adolescents' citizenship norms.

We depart from three main research questions. First, we need to ascertain whether these two forms of citizenship norms indeed can be empirically distinguished, both in the 1999 and the 2009 data. If this is the case, the second research question is whether we observe a decline of more traditional, institution- and duty-based citizenship norms and a corresponding rise in engaged or critical citizenship norms. The third question is whether the engaged citizenship norms are most prevalent in the most affluent and stable democracies, as post-modernization theory argues. The 1999 and 2009 data can be used to address these questions, since both surveys were conducted among the same age group, used the same methodology, and reached comparable levels of representativeness.

Both surveys were conducted among adolescents, which is ideal for our purpose since the literature states that new citizenship concepts will emerge first among younger age groups (Eckstein, Noack \& Gniewosz 2012; Hooghe \& Dassonneville 2013). Although we cannot yet adequately investigate participation among adolescents since they are still excluded from electoral participation, research shows that citizenship norms can be studied in a meaningful and valid manner among adolescents (van Deth, Abendschön \& Vollmar 2011). Yet, we also need to acknowledge that the democratic ideals of adolescents are still in a developing phase (Flanagan 2013) so it remains to be investigated how these norms will change once they enter early adulthood. We address this limitation more fully in the discussion section of this article.

\section{DATA AND METHODS}

If we want to use survey data to investigate changes over time, it is important that research design and data gathering methods are strictly comparable. For this reason, we selected two 
surveys, both conducted in a similar manner by the International Association for the Evaluation of Educational Achievement (IEA). This organization is responsible for comparative evaluation studies of education systems, and in 1999 and 2009 civic education was the focus of such an effort, just as in the past IEA conducted tests of students' language and mathematical skills. While these data have not been routinely used in sociological or political science research, the school-based approach of the fieldwork ensures a high level of representativeness for this age group.

Both surveys were conducted in the same manner, as educational authorities in the participating countries were responsible for fieldwork and quality control. The survey was conducted in school classes, and in most countries educational authorities implemented the survey themselves. This design resulted in high response rates, and representative samples for the school population of 14 year olds. In 1999, the IEA Civic Education Study (Cived) was conducted among 90,000 respondents in 28 countries (Torney-Purta et al. 2001). Ten years later, a similar design was followed for the International Civic and Citizenship Education Study (ICCS) (Schulz, Ainley \& Frailon 2011), this time including information from 140,000 respondents in 38 countries.

Both surveys can be directly compared as they use the same methodology and target the same age group. In total 21 countries participated in both surveys, the majority of which are in Europe, but with also a few countries in Asia and Latin America. In order to compare the 1999 and the 2009 data in a reliable manner we limit the analysis to the following 21 countries for which we have comparable data: Bulgaria, Switzerland, Chile, Columbia, Cyprus, Czech Republic, Denmark, England, Estonia, Finland, Greece, Hong Kong, Italy, Lithuania, Latvia, Norway, Poland, Russia, Slovakia, Slovenia and Sweden. ${ }^{1}$ The main and unique appeal of these two datasets is that they include a comprehensive battery on citizenship norms. A rather straightforward way to analyze this survey would be to 
construct attitudinal scales (e.g., based on a factor or principal component analysis), and to use these as the main dependent variable. Such an approach would be completely valid as a research design. However, in the literature on changing citizenship norms it is clear that the main concern is about individuals, not about attitudes as such. The expectation is that groups of individuals will strongly emphasize one set of values or preferences, while they disregard another set. Exactly this combination of preferences renders them 'engaged', 'critical' or 'self-expressive'. If we applied traditional attitude-focused regression analysis, it would be impossible to detect this specific combination. For example, with a traditional analysis of attitude scales or regression analysis we could arrive at the conclusion that girls score higher on civic duty and lower on critical engagement, but these kinds of findings would not mean that there is actually a group of girls that make this very distinctive combination. In order to test the theory in a valid manner, therefore, rather than focus on the prevalence of an attitude, we examine combinational patterns made by specific groups of individuals. This kind of actor-centered approach traditionally used cluster analysis, but given the important problems with regard to the identification of specific clusters of groups, this kind of approach by now has been largely abandoned. In the more recent literature, actor-centered analyses mainly relied on latent class analysis or related techniques, as these allow us to identify latent classes on the basis of reliable goodness of fit statistics (Collins \& Lanza 2010). While latent class analysis (LCA) is not yet routinely used in the study of political attitudes, it is by now widely applied e.g. in medical sociology, and in this article we use this technique to investigate changing citizenship concepts (Hagenaars \& Halman 1989; Magidson \& Vermunt 2004; Yuan et al. 2014).

In recent years the application of LCA as a probabilistic form of cluster analysis became widespread in various fields in the social sciences. The technique allows for the clear identification of subgroups within a population, combining a similar set of characteristics 
(Keel et al. 2004; Wolf et al. 2012). The main difference between LCA (and related techniques) and factor analysis is that the grouping of observed data for factor analysis is based on the correlation between indicators, whereas for LCA the grouping is based on an actor-centered approach that identifies respondents who share similar patterns of answers in a survey. In terms of the research interest in this article of identifying groups with specific sets of citizenship norms, factor analysis could help us to identify how variables group together into separate 'dimensions of citizenship' (Dalton 2008: 80-81), whereas LCA can directly assess the theory that distinctive groups of people share specific citizenship norms. Model selection in LCA is guided by goodness of fit criteria and stability statistics, and this is an advantage compared with traditional cluster analysis where the number of clusters often depends on rather arbitrary decision rules (Yang 2006). We also use multilevel analysis to ascertain whether economic development and democratic stability of a country have an impact on the prevalence of specific citizenship norms.

\section{RESULTS}

Our analysis proceeds in three steps. First we ascertain whether it is possible to identify distinct citizenship concepts, both in the 1999 and the 2009 dataset. Subsequently we investigate whether the trend over time corresponds to theoretical ideas about value change in contemporary society. Third, we analyze differences between countries.

\section{Results: Cived 1999}

In both the 1999 and 2009 surveys, respondents were asked to explain what a good citizen is or does. Subsequently the respondent received a list of twelve different activities and was requested to rank these activities on a four-point scale of importance: two categories that rated the item as not important ('not important at all' and 'not very important'), and two 
response categories that rated the item as important ('quite important' and 'very important'). ${ }^{2}$ In this article, we present LCA findings based on the more parsimonious two-category coding that makes a distinction between behaviors that respondents consider to be not important (0) and behaviors that respondents consider important (1). Although this two-category coding scheme entails a loss of variance, an important advantage of this coding is that we can be confident of cross-country metric equivalence (Agresti, 2007; Kankaraš, Moors \& Vermunt, 2010; Kankaraš \& Vermunt, 2014)

Most of the activities in the scale receive high scores (Table 1). A vast majority of respondents considers obeying the law important for a good citizen, but protecting the environment, defending human rights or voting in elections are also generally seen as important. Discussing politics and party membership, on the other hand, are seen as important by only a minority of respondents.

[Table 1 About Here]

A first step in the analysis is to determine the number of latent classes that should be distinguished. A crucial advantage of latent class analysis is that the Bayesian Information Criterion (BIC) allows researchers to identify the model (including the number of groups) that matches most closely with the structure of the dataset. The BIC can be used to identify a unique best model, which obviously was not the case in more traditional cluster analysis (Nylund, Asparoutiov \& Muthen 2007). Although one model selection approach is to opt for the absolute lowest BIC value, in research on complex attitudinal concepts it is common to base model selection on a declining BIC, along with the percent change in the likelihood ratio chi-square statistic and the classification error (Magidson \& Vermunt, 2004: 176-177). Using these model selection criteria suggests that five latent classes provide an optimal fit to these 
data. Models where we try to identify two, three, four or six latent groups do not offer a better match with the structure of the data. ${ }^{3}$ A test for measurement equivalence in both observation points confirmed the cross-national metric equivalence of the latent classes, which means that the citizenship concepts can be validly compared across countries. ${ }^{4}$ In the online appendix we document the LCA fit statistics and conditional probabilities findings for all countries separately in both observation points. These findings show that fit statistics support the model choice considerations in the pooled sample: individual country analyses tend to show a major improvement in fit up through the five-cluster model, after which point an increased number of classes provides limited improvement in model fit. Regarding the conditional probabilities, the findings show an overall stability in the findings based on the two observations. For all countries, versions of the five main citizenship norms are present, even though individual countries sometimes have idiosyncratic emphases. This analysis therefore confirms the crossnational and cross-time measurement equivalence of our key theoretical constructs.

[Table 2 About Here]

Three of these latent classes are represented in Figure 1 by grey markers, where the markers represent the probability that respondents belonging to that specific latent group consider each activity to be (very) important for what an adult good citizen should do. The latent class probabilities can be compared with the population mean for each indicator, which is listed in parentheses underneath the $\mathrm{x}$-axis. This comparison shows that each one of the classes has a unique pattern of combining specific preferences.

The largest of these groups, including a quarter of the sample, is what we would label an 'all-around' citizen. This group is distinct because it considers almost every act as important. The probabilities are only somewhat lower for protesting, discussing politics and 
joining a party, but they are still well above average. In contrast, the group we refer to as the 'mainstream' citizen (21 per cent of all respondents) is largely on par with the sample mean on the indicators. Although this group has some deviations from the sample mean, such as a relatively high emphasis on work and news, and a relatively low emphasis on respect and party, this group largely reflects the average scores on indicators for good citizenship. Finally, in contrast to the 'all-around' citizens, we also find a sizeable group of respondents (16 per cent) that has very low average scores. This group has a relatively high emphasis, however, on working hard and obeying the law, so in line with traditional political culture research, they can be referred to as 'subjects' (Almond \& Verba 1963).

[Figure 1 About Here]

The two theoretically most interesting groups are represented by black markers with connecting lines in Figure 1. As the figure indicates, the two latent classes of engaged and duty-based citizens have distinctive normative preferences. For the sake of clarity we will refer to those groups as respectively engaged and duty-based citizens. 'Engaged' citizens (16 per cent) are likely to consider the protection of the environment and human rights as important, and they also place emphasis on being active in the local community. At the same time, however, this group is less likely to consider traditional duty-bound acts to be important, such as working, voting, respecting government officials, and joining a party. This group therefore most closely represents Dalton's concept of 'engaged citizenship'. While their emphasis on human rights and the environment is in line with the theories of Inglehart and Welzel (2005), their focus on local level civic engagement resembles most closely the ideas put forward by Dalton (2008). 
Likewise, the 'duty-based' group ( 22 per cent) is close to the ideal type of traditional, civic duty-based citizenship. In contrast to the engaged citizens, this group emphasizes traditional acts like voting, showing respect, and watching the news. Even though the dutybased citizens have an active sense of traditional political duty, they do not highly value protecting the environment and human rights. As such, this group emphasizes the importance of institutionalized and electoral politics, while it does not pay much attention to typical postmodern sensitivities. Although the work of Norris (2011) does not refer explicitly to this rather traditional group, it is clear that their preferences are exactly the opposite from what she labels as 'critical citizens'.

This analysis of the Cived 1999 data confirms the empirical validity of two sets of citizenship norms that can be referred to as engaged and duty-based. It has to be noted, however, that the engaged and duty-based groups combined amount to only 38 per cent of all respondents. Almost two-thirds of the respondents in 1999 do not hold these citizenship norms. Rather surprisingly, 16 per cent of respondents adhere to very traditional citizenship norms, by emphasizing obeying the law and working hard.

\section{Results: ICCS 2009}

Subsequently, we proceed in the same manner, with the 2009 ICCS survey data. When looking at the frequencies (Table 3), a first observation is that there is not much difference in comparison to the 1999 results (Table 1). Obeying the law remains the most-often mentioned item, while party membership remains lowest on the priority list. For all twelve items the differences between the scores in 1999 and those in 2009 remain rather limited, and at first sight a simple look at the population averages might suggest stability over this ten year period. Latent class analysis however allows us to determine the underlying trends. 


\section{[Table 3 About Here]}

As in our analysis of the ICCS 2009 data, we first determine the optimal number of latent classes. Goodness-of-fit measures again indicate a clear preference for a five latent classes solution which allows for a valid comparison over time.

\section{[Table 4 About Here]}

In Figure 2, five latent classes are plotted for the 2009 data, which in many ways parallel the 1999 findings. Again, the 'all-arounders' are the largest group (35 percent of all respondents). As ten years earlier, members of this group tend to answer that everything is important, and they have the highest probabilities to consider every single item to be important. It can be noted, however, that in 2009 this group places less emphasis on party membership and engaging in political discussions. While in 1999, 65 percent of the group members considered party membership to be important, this was down to 51 per cent in 2009.

While the 'engaged' group only amounted to 16 percent of all respondents in 1999 , this group increases to 30 per cent in 2009. This sharp rise supports the claim that engaged citizenship norms are on the rise in contemporary society. The profile of the engaged group is very similar in both surveys, with high scores for human rights, the environment and being active in the local community, while this group remains skeptical about voting and joining a political party. The group of engaged citizens is thus very similar in both surveys, but it almost doubles in size compared to the 1999 results. As far as we know, this is the very first time the rise of engaged citizenship norms has been demonstrated in an unequivocal manner for such a broad range of countries.

A third group identified in the analysis is the duty-based citizens, and this group falls from 22 per cent in 1999 to 15 per cent in 2009. The group is again characterized by high 
scores for voting and respecting authority, but protecting rights and the environment and being active in the local community become even less important for this group. Again in 2009 we see a 'mainstream citizens' cluster which roughly echoes the emphases of the population average, though this group is smaller in 2009. Finally, the percentage of 'subjects' declines from 16 to six per cent, and they remain attached to obeying the law and working hard.

[Figure 2 About Here]

In sum, both in 1999 and in 2009 distinctive groups of engaged and duty-based citizens could be identified, together with three additional groups (i.e., the all-around, mainstream and subject groups). At first sight, these findings confirm our claim that it was appropriate to use an actor-based form of analysis. However, the question remains: did the use of latent class analysis lead to theoretically superior results, compared to a more standard attitude-based analysis? To assess this, we conducted an additional analysis that relies purely on a factor analysis. Factor analyses based on the data from 1999 and 2009 show that all items load primarily on one factor. In both 1999 and 2009 the main component has a very large eigenvalue (2.612 in 1999 and 2.856 in 2009) while the other two components have eigenvalues close to 1.0. In both observations, the first factor explains more than twice the variance as the next largest factor. These findings corroborate Bolzendahl and Coffé's (2013: 69) report that a factor analysis of the 25 Eastern and Western European countries in the International Social Survey Programme in 2004 led to just one factor which lumped together various citizenship items. A closer look at the latent class analysis findings shows why a traditional factor analysis is so inconclusive. The huge percentage of all-around and mainstream group respondents (almost half of the total sample in both measurements) attributes high values to a wide range of items, and this leads to one large and theoretically 
unsatisfactory factor where all items are lumped together. The factor analysis is completely dominated by this group, so that it does not allow us to observe what goes on in the other smaller groups that are of theoretical interest in this paper. The latent class analysis, on the other hand, is much more precise in this crucial aspect and it allows us to gain new insights in this process of value change among specific groups of the population.

\section{Results: Comparison 1999-2009}

The previous results indicated that duty-based and the engaged citizenship norms can be empirically distinguished, both in 1999 and 2009. We have also seen that engaged citizenship norms became more prevalent, while the opposite trend has been observed for duty-based citizenship norms. We emphasize, however, that in both observation periods more than half of the respondents do not fit into either of these two categories. While much of the theoretical literature is focused only on engaged and duty-based groups, it is important to remember that in a wide variety of industrialized democracies young people continue to adhere to other norms, including very traditional ones.

As we focus on comparing the engaged and duty-based groups in 1999 and 2009, Figures 3 and 4 show that these norms are largely similar in both observations, but that we can also observe some subtle changes. For the engaged citizens (Figure 3) human rights and the environment remain of paramount importance, but we can observe that discussing politics is rated slightly lower in 2009. Knowing the history of one's country on the other hand, receives a higher rating than in 2009. The main defining elements of the engaged citizenship norm are almost identical in both observations, strengthening the argument that this concept can be compared over time. 
[Figure 3 About Here]

In Figure 4, we compare the characteristics of the duty-based norm. In general, this group rates the various acts lower in 2009 than it did in 1999, so it seems that even among this group the idea of a 'duty' to perform these acts gets weaker. Defining characteristics of this group endure, however, such as respecting authority, and working hard (which has an even higher likelihood in 2009). So while the group of duty-based citizens becomes smaller, it develops a more distinct normative profile, with stronger differences between acts that are considered important and those that are not.

[Figure 4 About Here]

In sum, our first research question whether engaged and duty-based citizenship norms can be empirically identified was confirmed. In both 1999 and in 2009 the LCA indicated that both of these norms are present, with rather small differences regarding the relative emphases of these norms in both observations. The second research question also can be answered in an affirmative manner (Figure 5): the proportion of engaged citizens rises (from 15 to 30 per cent) while the duty-based citizenship norms loses support (from 22 to 15 per cent). These findings support the claim that the decline of duty-based citizenship and the accompanying rise of engaged citizenship are present across industrialized democracies.

[Figure 5 About Here] 


\section{Results: Comparative Analysis}

Thus far, we have presented analyses for a wide range of 21 different societies, but these trends should also be investigated in a comparative manner. It is relevant to determine whether similar trends can be found in all of these countries separately. First we present an overview of our findings that compares geographical regions. In most of the literature on value change in contemporary society, it is assumed that especially the Scandinavian countries and Western Europe will be frontrunners in the trend toward new normative sensitivities, such as support for human rights or the environment. The figures in Table 5 show that this was indeed still the case in 1999: the engaged citizenship concept was most strongly present in the Scandinavian countries (with 37 percent of all respondents) and in Western Europe (30 percent of all respondents), while less than 10 percent of respondents adhered to this norm in other regions, including Mediterranean Europe, Central and Eastern Europe, and South America and Asia. The 1999 results thus clearly follow the pattern we would expect based on the literature with regard to postmateralism. For 2009, however, it can be observed that this trend reversed, with a decline of engaged citizenship in the Scandinavian countries and Western Europe and a simultaneous rise of engaged citizenship in all other regions. This distribution clarifies that some of the conventional wisdom about more contemporary value orientations being present mainly in Northern and Western Europe no longer seem to be valid in the most recently available figures. Especially the countries in Asia and Latin America seem to have experienced a rapid transition toward more engaged citizenship norms among adolescents, although it has to be acknowledged that the number of participating countries in those remains limited.

[Table 5 About Here] 
The country-specific findings challenge an assumption often made in this line of research that changes in citizenship norms and political attitudes follow a typical pattern where Nordic countries take the lead, while newly emerging democracies are slower to adapt to the new trends (Inglehart, 1997). In the appendix we list the country figures for the distribution of the citizenship norms, both in 1999 and in 2009 (Tables A1 and A2). These findings show that in the Cived study in 1999, the assumption about the geographic distribution of this trend is still rather valid as we find the highest proportion of engaged citizens in Nordic countries like Denmark, Norway and Sweden. In 2009, however, these citizenship norms can equally be found in Latin America or the Baltic states, and the Nordic countries are no longer exceptional. The theoretical relevance is that while Northern and Western Europe traditionally have been depicted as frontrunners in the trend toward new citizenship norms, at least among adolescents their position clearly is no longer exceptional. In order to test these differences between countries in a more rigorous manner, we conducted a multilevel regression analysis, including both individual and country level independent variables. On the individual level, we keep the information to a minimum, by including for only gender and socio-economic status. In this kind of data, it is usually not possible to obtain reliable information from the adolescent respondents about family income or professional status of the parents. Therefore, a routine solution is to ask adolescents about the number of books at home as a proxy for socio-economic status. On the country level, we include the years of stable democracy and GDP per capita (Inglehart \& Catterberg, 2002). Given the fact that the number of observations on the country level is limited, both indicators had to be included one by one. In line with the literature, our hypothesis is that both democratic stability and economic status will have a positive effect on engaged citizenship and a negative one on duty-based citizenship. 
The results of the multilevel regression analysis (Table 6) confirm expectations for the 1999 data (see appendix for descriptive statistics). For duty-based citizenship there is a significantly negative effect of both the years of stable democracy and the GDP per capita, while we find exactly the opposite relation for engaged citizenship in 1999. When we subsequently conduct the same analysis for the 2009 data, we obtain exactly the opposite result, with less engaged citizenship in countries with a long history of stable democracy and high economic development level. Our finding that the Scandinavian and established Western European countries have lost their front runner position in this regard is thus confirmed by the results of this comprehensive multilevel regression test. At least among adolescents, the spread of new citizenship norms seems to have become a more global phenomenon, that is no longer concentrated in specific geographic regions.

[Table 6 About Here]

\section{DISCUSSION}

In this study, we conduct a major comparative analysis of trends in citizenship norms in 21 countries, exploiting the availability of new survey data on citizenship norms among adolescents. One of the advantages of working with these data is that they allow for a rigorous research design that maps trends over time in an empirically valid manner.

The results of the study largely confirm the claims put forward in the literature on value change. First, both engaged and duty-based citizenship norms can be identified in an empirically valid manner, and secondly, we can observe that engaged citizenship is on the rise while duty-based citizenship is declining. Even more strongly than the literature expects, these findings indicate a very general trend that is also present in Latin American and in Central and Eastern Europe. Value change thus indeed proceeds in the way authors like Inglehart, Norris, Schudson and Dalton suggested. Simultaneously, however, a very large part 
of the sample does not fit into this theoretical framework, and respondents in the largest of these groups have the tendency to state that everything is important. This 'all-around' group is even so large that in a factor-based regression analysis, it overwhelms the entire pattern. An actor-centered analytical technique like latent class analysis is required to detect the occurrence of the smaller groups that are central in the theoretical literature. Our findings show that while these 'pioneer' groups may be highly relevant from a theoretical point of view, they do not constitute a majority among this age group.

Our findings deviate from Dalton's claim, however, in a different manner. What we can observe from a direct comparison between these data in 1999 and 2009 is that there is very little change in the overall importance attached to the various items. Adolescents in 2009 state that voting and obeying the law are of the utmost important for being a good citizen, just like their counterparts did in 1999. The importance of these 'traditional' acts of good citizenship did not diminish. What does differ, however, is the way adolescents consider these traditional acts to be important when examined as part of a broader citizenship norm that simultaneously takes other aspects of good citizenship into account. When we analyze these data, we observe that the group that emphasizes the importance of voting and obeying the law becomes a smaller proportion of the population, in favor of groups that have different priorities for good citizenship. So, while our analysis supports the trend toward the increased prevalence of 'engaged citizenship', we can also see that more traditional and institutionalized acts of citizenship participation, like voting, are still considered as important and will not be easily replaced in the near future.

The evidence for the geographical distribution of citizenship norms across countries is rather mixed. For the 1999 data expectations were confirmed, as we did find the highest prevalence of engaged citizenship norms in Scandinavia, and in other countries with a stable democratic tradition and a high economic development level. Ten years, later, however, this 
pattern is reversed. This questions the theoretical assumption that the trend toward postmaterialist value orientations can be regarded as a purely linear process. Apparently other countries caught up with the high levels that were already present in the Scandinavian countries more than a decade ago. Tentatively, this could indicate that at least among adolescents, the Scandinavian countries have lost their exceptional status, and that the spread of these new norms has become a much more global phenomenon. It has to be remembered, however, that we have few countries from these regions in our dataset, so that broader data are necessary to arrive at a more comprehensive assessment of these trends. An alternative plausible explanation for this trend might be that the questions also probe into what adolescents consider to be most salient. For adolescents in Scandinavia, protecting the environment or human rights might not be considered as highly salient, because the governments in those countries have already taken numerous initiatives to incorporate these sensitivities in their policies. For the adolescents in Latin America, on the other hand, this might seem a highly salient issue, exactly because adequate government policy is missing. To what extent this is not just a plausible, but also a likely explanation, however, still needs to be investigated.

A number of caveats are in order. First, while the identified citizenship norms are remarkably similar in both surveys, they are obviously not identical. The most characteristic items, however, do remain firmly in place, thereby confirming that a comparison over time is warranted. The analysis suggests, however, that duty-based citizenship not only becomes less prevalent over the observation period, but also that the specific element of 'duty' become diluted as members of this group are less likely in 2009 to consider a whole range of dutybased acts as important. In addition, it is worth emphasizing that both surveys were conducted among adolescents, and we wish to elaborate upon our prior observation there are different positions in the literature about the theoretical status of political attitudes among adolescents. 
The remarkable stability of the 1999 and 2009 LCA solutions, suggests that these adolescents did not respond in a random manner, but that there is a distinct pattern in their answers. In line with previous research, these findings indicate that citizenship norms can be measured in a valid manner among adolescents.

A question remains, however, regarding the relationship between normative beliefs of adolescents and their adult counterparts. On the one hand, some authors make the point that there tends to be a strong pattern of stability between adolescence and early adulthood (Quintelier \& Hooghe 2012). Following this assumption would allow us to predict that the adolescent respondents in these surveys to a large extent will continue to have the same political preferences as they mature into adulthood. On the other hand, authors in the field of developmental psychology suggest that adolescents are still in developmental phases in the lifecycle, during which actors continue to develop their moral and cognitive concepts and identities (Flanagan 2013). This line of the literature would suggest that there will be important differences between the citizenship concepts of adults and adolescents. For example, the large proportion of respondents that highly value obeying the law is consistent with traditional findings in developmental psychology that authority beliefs are strong among this age group (Smetana \& Turiel 2003). Since we are unaware of any comparative dataset among adults that includes a similar over-time battery of citizenship concepts, it remained beyond the scope of this article to investigate or explain differences between adolescents and adults. In future research, it would be highly relevant to make such a direct comparison between citizenship concepts among adolescents and adults, as only such a test provides the necessary information to ascertain whether our finding could be generalized toward a larger population.

Our findings generate a number of new research questions. In line with Dalton's change thesis, we can observe that the group that finds it important to defend human rights 
and to work in the local community has become larger over time. Yet, it remains to be seen whether and how this preference for local and non-institutionalized participation enables the establishment of a meaningful linkage mechanism between citizens and the political system. Various authors have already documented how political decision-making tends to shift toward a higher geographic scale as a reaction to economic and ecological demands (Stiglitz 2007). Simultaneously, however, the citizens of tomorrow, as we might label these adolescents, increasingly seem to prefer local and non-institutionalized engagement. One cannot help but wonder how effective this form of engagement can be, and if in fact 'engaged citizenship' may be tantamount to citizens losing their clout in the process of political decision-making. 


\section{Endnotes}

1. Belgium took part in both surveys but in 1999 only French language schools participated, and in 2009 only Dutch language schools. Therefore, Belgium was left out of the comparison.

2. The 1999 questionnaire also included 'willing to serve in the military to defend the country' as a possible act, but this question was not repeated in the 2009 questionnaire and was therefore left out of the analysis presented in this article. When we do include this item for the 1999 analysis, the findings are in line with our theoretical expectations for the duty-based and engaged citizenship norms: in comparison to the average respondent, engaged citizens are less likely to be willing to serve in the military, whereas the duty-based group is more willing.

${ }^{3}$ Although one could argue that the 6-class solution adds model fit value, the advantage is minimal in terms of the goodness of fit statistics. Our investigation of the substantive solution of the 6-class model revealed why this is so: the additional sixth cluster that is gained simply splits the duty-based cluster into two separate duty-based groups that are differentiated only by one group's slightly higher overall conditional probabilities. In addition to the fit statistics, therefore, the theoretical insights gained in the transition to the 6-cluster model do not justify the selection of a more complex model. This was also true for the 2009 analysis and modelselection.

${ }^{4}$ These measurement equivalence tests follow the logic and syntax detailed in Kankaras, Moors \& Vermunt (2010). Evidence of metric measurement equivalence is found when the partial equivalence model has a BIC that is lower than the hetergoenous model. Metric equivalence was supported by findings for the 1999 data (BIC for heterogenous model $=$ 578793; for partial equivalence model $=572275$ ) and for the 2009 data (BIC for heterogenous model $=792306$; for partial equivalence model $=786543$ ). Additional tests for scalar equivalence (i.e. whether citizenship items have the same intercept across countries) indicated that the model lacks scalar equivalence. By retaining direct effects for each item in the model, LCA allows the intercept for the items to vary for each country, which enables valid crosscountry comparisons of the same latent class constructs. 


\section{References}

Agresti, A. (2007). An Introduction to Categorical Data Analysis (2nd ed.). Hoboken, N.J.: Wiley.

Almond, G.A., \& Verba, S. (1963). The Civic Culture. Princeton NJ: Princeton University Press.

Bennett, W.L. (2012). The Personalization of Politics: Political Identity, Social Media, and Changing Patterns of Participation. Annals of the American Academy of Political and Social Science, 644(1), 20-39.

Bennett, W.L. and Segerberg, A. (2013). The Logic of Connective Action. Digital Media and the Personalization of Contentious Politics. Cambridge: Cambridge University Press.

Blais, A., E. Gidengil and N. Nevitte (2004). Where Does Turnout Decline Come From? European Journal of Political Research, 43(2), 221-236.

Blais, A., \& Rubenson, D. (2013). The Source of Turnout Decline: New Values or New Contexts? Comparative Political Studies, 46(1), 95-117.

Bobek, D., Zaff, J., Li, Y., and R.M. Lerner (2009). Cognitive, Emotional, and Behavioral Components of Civic Action. Towards an Integrated Measure of Civic Engagement. Journal of Applied Developmental Psychology, 30(5), 615-627.

Bolzendahl, C., \& Coffé, H. (2013). Are 'Good' Citizens Good' Participants? Testing Citizenship Norms and Political Participation Across 25 Nations. Political Studies, 61(S1), 45-65.

Castells, M. (2000). The Rise of the Network Society. Oxford: Blackwell.

Collins, L.M., \& Lanza, S.T. (2010). Latent Class and Latent Transition Analysis: With Applications in the Social, Behavioral, and Health Sciences: Wiley.

Copeland, L. (2014). Value Change and Political Action: Postmaterialism, Political Consumerism, and Political Participation. American Politics Research, 42(2), 257282.

Dalton, R. J. (2000) Citizen Attitudes and Political Behavior, Comparative Political Studies, 33(6-7), 912-40.

Dalton, R. J. (2007). The Good Citizen. How a Younger Generation is Reshaping American Politics. Washington D.C.: CQ Press.

Dalton, R. J. (2008). Citizenship Norms and the Expansion of Political Participation. Political Studies, 56(1), 76-98.

Dalton, R.J. (2013). Citizen politics: Public opinion and political parties in advanced industrial democracies (6th ed.). Washington, DC: CQ Press.

Dalton, R.J. \& C. Welzel (eds., 2015). The Civic Culture Transformed. From Allegiant to Assertive Citizens. Cambridge: Cambridge University Press.

Deth, J. van, Abendschön, S., and Vollmar, M. (2011). Children and Politics: An Empirical Reassessment of Early Political Socialization. Political Psychology, 32(1), 147-174.

Eckstein, K., Noack, P., and Gniewosz, B. (2012). Attitudes Towards Political Engagement and Willingness to Participate in Politics: Trajectories Throughout Adolescence. Journal of Adolescence, 35(1), 1-11.

Eliasoph, N. (2013). Making Volunteers: Civic Life after Welfare's End. Princeton: Princeton University Press.

Fieldhouse, E., Tranmer, M., \& Russell, A. (2007). Something About Young People or Something About Elections? Electoral Participation of Young People in Europe: Evidence from a Multilevel Analysis of the European Social Survey. European Journal of Political Research, 46(6), 797-822.

Flanagan, C. (2013). Teenage citizens. Cambridge: Harvard University Press. 
Giddens, A. (1991). Modernity and Self-Identity. Cambridge: Polity.

Hagenaars, J.A., \& Halman, L.C. (1989). Searching for Ideal Types: The Potentialities of Latent Class Analysis. European Sociological Review, 5(1), 81-96.

Hooghe, M., \& Dassonneville, R. (2013). Voters and Candidates of the Future. The Intention for Electoral Participation among Adolescents in 22 European Countries. Young: Nordic Journal of Youth Research, 21, 1-28.

Hooghe, M., Oser, J., \& Marien, S. (forthcoming). A Comparative Analysis of 'Good Citizenship': A Latent Class Analysis of Adolescents' Citizenship Norms in 38 Countries. International Political Science Review. http://ips.sagepub.com/content/early/2014/07/24/0192512114541562.abstract

Howe, P. (2010). Citizens Adrift: The Democratic Disengagement of Young Canadians. Vancouver: UBC Press.

Inglehart, R. (1997). Modernization and Postmodernization. Cultural, Economic, and Political Change in 43 Societies. Princeton: Princeton University Press.

Inglehart, R. and Catterberg, G. (2002). Trends in Political Action: The Developmental Trends and the Post-Honeymoon Decline, International Journal of Comparative Sociology, 43, 300-17.

Inglehart, R. and C. Welzel (2005). Modernization, Cultural Change, and Democracy. The Human Development Sequence. New York: Cambridge University Press.

International Monetary Fund. 2013. World Economic and Financial Surveys: World Economic Outlook Database. Last accessed: February 22, 2015. http://www.imf.org/external/pubs/ft/weo/2013/01/weodata/index.aspx

John, P., E. Fieldhouse and H. Liu (2011). How Civic is the Civic Culture? Explaining Community Participation Using the 2005 English Citizenship Survey. Political Studies, 59(2), 230-252.

Kankaraš, M., Moors, G., \& Vermunt, J.K. (2010). Testing for Measurement Invariance with Latent Class Analysis. In E. Davidov, P. Schmidt \& J. Billiet (Eds.), Cross-Cultural Analysis: Methods and Applications (pp. 359-384). New York: Routledge.

Kankaraš, M., \& Vermunt, J.K. (2014). Simultaneous latent class analysis across groups. In A. C. Michalos (Ed.), Encyclopedia of Quality of Life and Well-Being Research. Heidelberg: Springer.

Keel, P. et al. (2004). Application of a latent class analysis to empirically define eating disorder phenotypes. Archives of General Psychiatry, 61(2), 192-200.

Klingemann, H.D. (2015). Dissatisfied Democrats. Democratic Maturation in Old and New Democracies, pp. 116-157 in R. Dalton \& C. Welzel (eds.), The Civic Culture Transformed: From Allegiant to Assertive Citizens. Cambridge: Cambridge University Press.

Magidson, J., and Vermunt, J. K. (2004). Latent Class Models. In D. Kaplan (Ed.), The Sage Handbook of Quantitative Methodology for the Social Sciences (pp. 175-198). London: Sage.

Marien, S., Hooghe, M. and E. Quintelier (2010). Inequalities in Non-Institutionalized Forms of Political Participation. A Multilevel Analysis for 26 Countries. Political Studies, 58(1), 187-213.

Marshall, Monty G., Ted Robert Gurr, and Keith Jaggers. 2011. Polity IV Project: Political Regime Characteristics and Transitions, 1800-2013, Dataset Users' Manual. Vienna: Center for Systemic Peace. Retrieved from www.systemicpeace.org/inscrdata.html. Last accessed: February 22, 2015.

Martin, A. (2012). Political Participation among the Young in Australia: Testing Dalton's Good Citizen Thesis. Australian Journal of Political Science, 47(2), 221-226. 
Norris, P. (2002). Democratic phoenix: Reinventing political activism. Cambridge: Cambridge University Press.

Norris, P. (2011). Democratic deficit: Critical citizens revisited. Cambridge University Press, Cambridge.

Norris, P. (ed., 1999). Critical Citizens. Oxford: Oxford University Press.

Nylund, K., Asparoutiov, T., and Muthen, B. (2007). Deciding on the number of classes in latent class analysis and growth mixture modeling: A Monte Carlo simulation study. Structural Equation Modeling, 14(4), 535-569.

Oser, J., \& Hooghe, M. (2013). The Evolution of Citizenship Norms among Scandinavian Adolescents, 1999 - 2009. Scandinavian Political Studies, 36(4), 320-346.

Pharr, S., and Putnam. R. (Eds., 2000). Disaffected Democracies: What is Troubling the Trilateral Countries?, Princeton: Princeton University Press.

Quintelier, E. and Hooghe, M. (2012). Political Attitudes and Political Participation: A Panel Study on Socialization and Self-Selection Effects among Late Adolescents. International Political Science Review, 33(1), 63-81.

Raney, T., \& Berdahl, L. (2009). Birds of a Feather? Citizenship Norms, Group Identity, and Political Participation in Western Canada. Canadian Journal of Political Science, 42(1), 187-209.

Schudson, M. (1998). The Good Citizen: A History of American Civic Life. New York: Martin Kessler Books.

Schulz, W., Ainley, J., and Fraillon, J. (eds., 2011). ICCS 2009 Technical Report. Amsterdam: IEA.

Shulman, H. and T. Levine (2012). Exploring Social Norms as a Group-Level Phenomenon: Do Political Participation Norms Exist and Influence Political Participation on College Campuses? Journal of Communication, 62(3), 532-552.

Sloam, J. (2013). "Voice and Equality": Young People's Politics in the European Union. West European Politics, 36(4), 836-858.

Smetana, J. and E. Turiel (2003). Moral Development during Adolescence, pp. 247-268 in G. Adams \& M. Berzonsky (eds.), Blackwell Handbook of Adolescence. Malden: Blackwell.

Stiglitz, J. (2007). Making Globalization Work. New York: Norton.

Stolle, D. and M. Hooghe (2011). Shifting Inequalities. Patterns of Exclusion and Inclusion in Emerging Forms of Political Participation. European Societies, 13(1), 119-142.

Straughn, J.B., and Andriot, A.L. (2011). Education, Civic Patriotism, and Democratic Citizenship: Unpacking the Education Effect on Political Involvement. Sociological Forum, 26(3), 556-580.

Torney-Purta, J.( 2001). Civic Knowledge, Beliefs about Democratic Institutions, and Civic Engagement among Fourteen Year Olds. Prospects, 31(3): 279-292.

Torney-Purta, J., Lehmann, R., Oswald, H., and Schulz, W. (2001). Citizenship and Education in Twenty-eight Countries: Civic Knowledge and Engagement at Age Fourteen. Amsterdam: IEA.

van Deth, J.W. (2007). Norms of citizenship. In R. J. Dalton \& H.-D. Klingemann (Eds.), The Oxford Handbook of Political Behavior (pp. 402-417). Oxford: Oxford University Press.

Vermunt, J.K. (2010). Latent class modeling with covariates: Two improved three-step approaches. Political Analysis, 18, 450-469.

Welzel, C. (2013). Freedom Rising: Human Empowerment and the Quest for Emancipation. Cambridge: Cambridge University Press. 
Welzel, C., \& Deutsch, F. (2012). Emancipative Values and Non-Violent Protest: The Importance of "Ecological" Effects. British Journal of Political Science, 42(2), 465 479.

Whiteley, P. (2011). Is the Party Over? The Decline of Party Activism and Membership Across the Democratic World. Party Politics, 17(1), 21-44.

Wolf, E., Miller, M., Reardon, A., Ryabchenko, K., Castille, D., and Freund, R. (2012). A Latent Class Analysis of Dissociation and Posttraumatic Stress Disorder Evidence for a Dissociative Subtype. Archives of General Psychiatry, 69(7), 698-705.

Yang, C. (2006). Evaluating latent class analysis models in qualitative phenotype identification. Computational Statistics and Data Analyiss, 50(4), 1090-1104.

Yuan, C., Wei, C., Wang, J., Qian, H., Liu, Y. and Hinds, P. (2014). Self-efficacy difference among patients with cancer with different socioeconomic status: Application of latent class analysis and standardization and decomposition analysis. Cancer Epidemiology, 38(3), 298-306.

Zukin, C., Keeter, S., Andolina, M., Jenkins, K., and Delli Carpini, M.X. (2006). A New Engagement? Political Participation, Civic Life, and the Changing American Citizen. New York: Oxford University Press. 
Table 1. Frequency of Good Citizenship Acts in Cived 1999

In this section there are some statements that could be used to explain what a good adult citizen is or what a good adult citizen does:

Obeys the law, votes in every election, joins a political party, works hard, would participate in a peaceful protest against a law believed to be unjust, knows about the country's history, follows the political issues in the newspaper, on the radio or on tv, participates in activities to benefit people in the community, shows respect for government representatives, takes part in activities to promote human rights, engages in political discussions, in activities to protect the environment.

\begin{tabular}{lrrrrrrrrrrrrrr} 
& obey & rights & \multicolumn{1}{c}{ local } & work & envir & vote & history & respect & news & protest & discuss & party \\
Mean & .95 & .84 & .83 & .81 & .81 & .80 & .73 & .72 & .72 & .68 & .44 & .31 \\
$\mathrm{~N}$ & 70451 & 67854 & 68617 & 68822 & 69054 & 69879 & 69026 & 67765 & 69078 & 65140 & 66166 & 66651 \\
Std. & .212 & .363 & .375 & .394 & .389 & .400 & .446 & .449 & .450 & .467 & .496 & .462 \\
$\begin{array}{l}\text { Deviation } \\
\text { Order }\end{array}$ & 1 & 2 & 3 & 4 & 5 & 6 & 7 & 8 & 9 & 10 \\
\hline
\end{tabular}

Source: Cived 1999, 21 countries, $n=72,543$. Entries are proportion of the respondents considering this act as (very) important for a good citizen. 
Table 2. LCA Model Fit Statistics for Citizenship Norms in 1999

\begin{tabular}{ccccc} 
& BIC $(\mathrm{LL})$ & $\mathrm{L}^{2}$ & \% change $\mathrm{L}^{2}$ & Class. Err. \\
\hline 1-Class & 639326 & 52627 & & 0.00 \\
2-Class & 603265 & 16425 & -0.69 & 0.11 \\
3-Class & 598406 & 11424 & -0.78 & 0.18 \\
4-Class & 596635 & 9512 & -0.82 & 0.23 \\
5-Class & $\mathbf{5 9 5 1 9 1}$ & $\mathbf{7 9 2 7}$ & $\mathbf{- 0 . 8 5}$ & $\mathbf{0 . 2 6}$ \\
6-Class & 594125 & 6719 & -0.87 & 0.29 \\
\hline
\end{tabular}

Source: Cived 1999. BIC = Bayesian Information Criterion; $L L=\log$ likelihood; $\mathrm{L}^{2}=$ likelihood ratio chi-square statistic. LCA findings using Latent Gold 4.5 software (Vermunt and Magidson 2005). Entries are test statistics for latent class models identifying one and more clusters of respondents. Additional commonly used test statistics were estimated (AIC AIC3, CAIC3) and were all in agreement with the BIC and the per cent change in $\mathrm{L}^{2}$ regarding the preferred model (in bold). 
Table 3. Frequency of Good Citizenship Acts in ICCS 2009

Report: How important are the following behaviours for being a good adult citizen?

Joining a political party, learning about the country's history, following political issues in the newspaper, on the radio, on TV or on the internet [Note: Internet was not mentioned in Cived 1999], showing respect for government representatives, engaging in political discussions, participating in peaceful protest against laws believed to be unjust, participating in activities to benefit people in the local community, taking part in activities promoting human rights, taking part in activities to protect the environment, working hard, always obeying the law.'

\begin{tabular}{|c|c|c|c|c|c|c|c|c|c|c|c|c|}
\hline & obey & rights & local & work & envir & vote & history & respect & news & protest & discuss & party \\
\hline Mean & .89 & .82 & .79 & .80 & .84 & .79 & .77 & .77 & .73 & .62 & .40 & .28 \\
\hline $\begin{array}{l}\text { Difference } \\
\text { in } 2009\end{array}$ & -.06 & -.02 & -.04 & -.01 & +.03 & -.01 & +.04 & +.05 & +.01 & -.06 & -.04 & -.03 \\
\hline $\mathrm{N}$ & 73421 & 73210 & 73214 & 73320 & 73284 & 73711 & 73153 & 73411 & 73463 & 73174 & 73279 & 73430 \\
\hline $\begin{array}{l}\text { Std. } \\
\text { Deviation }\end{array}$ & .314 & .381 & .405 & .400 & .367 & .404 & .422 & .424 & .444 & .484 & .490 & .448 \\
\hline Order: & 1 & 3 & 6 & 4 & 2 & 5 & 7 & 8 & 9 & 10 & 11 & 12 \\
\hline
\end{tabular}

Source: ICCS 2009, 21 countries, $n=75,020$. Entries are proportion of the respondents indicating that this behavior is (very) important for a good citizen. Indicators ordered from left to right in the same order as the ascending Cived means in Table 1; the 'Order' row ranks the indicators from most to least prevalent in the 2009 data. 
Table 4. LCA Model Fit Statistics for Citizenship Norms in 2009

\begin{tabular}{lcccc} 
& $\mathrm{BIC}(\mathrm{LL})$ & $\mathrm{L}^{2}$ & \% change $\mathrm{L}^{2}$ & Class. Err. \\
\hline 1-Class & 894867 & 91113 & & 0.00 \\
2-Class & 840078 & 36178 & -0.60 & 0.10 \\
3-Class & 827149 & 23104 & -0.75 & 0.15 \\
4-Class & 821190 & 17000 & -0.81 & 0.20 \\
5-Class & $\mathbf{8 1 7 3 5 4}$ & $\mathbf{1 3 0 1 9}$ & $\mathbf{- 0 . 8 6}$ & $\mathbf{0 . 2 2}$ \\
6-Class & 814928 & 10448 & -0.89 & 0.26 \\
\hline
\end{tabular}

Source: ICCS 2009. BIC = Bayesian Information Criterion; LL = log likelihood; L $^{2}=$ likelihood ratio chi-square statistics. LCA findings using Latent Gold 4.5 software (Vermunt and Magidson 2005). Entries are test statistics for latent class models identifying one and more clusters of respondents. Additional commonly used test statistics were estimated (AIC AIC3, CAIC3) and were all in agreement with the BIC and the per cent change in $\mathrm{L}^{2}$ regarding the preferred model (in bold). 
Table 5. Trends in Citizenship Norms across Regions of the World

\begin{tabular}{|c|c|c|c|c|c|}
\hline & Scandinavia & $\begin{array}{l}\text { Western } \\
\text { Europe }\end{array}$ & $\begin{array}{l}\text { Mediterranean } \\
\text { Europe }\end{array}$ & $\begin{array}{c}\text { Central \& Eastern } \\
\text { Europe }\end{array}$ & $\begin{array}{c}\text { South America \& } \\
\text { Asia }\end{array}$ \\
\hline & \multicolumn{5}{|c|}{ Prevalence of Engaged Norms } \\
\hline 1999 & 0.37 & 0.30 & 0.08 & 0.09 & 0.07 \\
\hline \multirow[t]{2}{*}{2009} & 0.28 & 0.18 & 0.14 & 0.34 & 0.42 \\
\hline & \multicolumn{5}{|c|}{ Prevalence of Duty-Based Norms } \\
\hline 1999 & 0.03 & 0.10 & 0.34 & 0.19 & 0.34 \\
\hline 2009 & 0.28 & 0.28 & 0.08 & 0.12 & 0.08 \\
\hline
\end{tabular}

Source: CivEd 1999; ICCS 2009. Note: percentage of all respondents adhering to one of the norm groups, for 1999 and 2009 based on LCA findings. Scandinavia: Denmark, Finland, Norway \& Sweden; Western

Eur.:Switzerland, England; Mediterr.: Cyprus, Greece, Italy; Central \& Eastern: Bulgaria, Czech Rep.;

Lithuania, Latvia, Poland, Russia, Slovak Rep., Slovenia; South Am. \& Asia: Chile, Columbia \& Hong Kong. 
Table 6. Multilevel Regression Model, Determinants of Duty-based and Engaged Norms

\begin{tabular}{|c|c|c|c|c|c|c|}
\hline 1999 & Duty I & Duty II & Duty III & Engaged I & Engaged II & Engaged III \\
\hline \multicolumn{7}{|l|}{ Individual level } \\
\hline Female & $\begin{array}{c}0.143 * * * \\
(0.034)\end{array}$ & $\begin{array}{c}0.150 * * * \\
(0.016)\end{array}$ & $\begin{array}{c}0.154 * * * \\
(0.015)\end{array}$ & $\begin{array}{c}0.247 * * * \\
(0.023)\end{array}$ & $\begin{array}{c}0.218 * * * \\
(0.016)\end{array}$ & $\begin{array}{c}0.214 * * * \\
(0.015)\end{array}$ \\
\hline \multicolumn{7}{|l|}{ SES proxy ${ }^{\mathrm{a}}$} \\
\hline 101-200 books & $\begin{array}{c}-1.003 * * * \\
(0.045)\end{array}$ & $\begin{array}{c}0.091 * * * \\
(0.021)\end{array}$ & $\begin{array}{c}0.076 * * * \\
(0.021)\end{array}$ & $\begin{array}{c}0.577 * * * \\
(0.030)\end{array}$ & $\begin{array}{c}0.005 \\
(0.021)\end{array}$ & $\begin{array}{l}-0.003 \\
(0.021)\end{array}$ \\
\hline 201 books+ & $\begin{array}{c}-0.943 * * * \\
(0.041)\end{array}$ & $\begin{array}{c}0.109 * * * \\
(0.020)\end{array}$ & $\begin{array}{c}0.086 * * * \\
(0.020)\end{array}$ & $\begin{array}{c}0.647 * * * \\
(0.028)\end{array}$ & $\begin{array}{l}-0.032 \\
(0.020)\end{array}$ & $\begin{array}{c}-0.047 * * \\
(0.019)\end{array}$ \\
\hline \multicolumn{7}{|l|}{ Country level } \\
\hline $\begin{array}{l}\text { Democracy } \\
\text { (years stable) }\end{array}$ & & $\begin{array}{c}-0.057 * * \\
(0.028)\end{array}$ & & & $\begin{array}{c}0.040 * * * \\
(0.015)\end{array}$ & \\
\hline GDP per capita & & & $\begin{array}{c}-0.013^{*} \\
(0.007)\end{array}$ & & & $\begin{array}{c}0.010 * * * \\
(0.003)\end{array}$ \\
\hline Constant & $\begin{array}{c}-3.486 * * * \\
(0.028)\end{array}$ & $\begin{array}{c}-4.159 * * * \\
(0.861)\end{array}$ & $\begin{array}{c}-4.181 * * * \\
(0.831)\end{array}$ & $\begin{array}{c}-4.134 * * * \\
(0.019)\end{array}$ & $\begin{array}{c}-3.727 * * * \\
(0.446)\end{array}$ & $\begin{array}{c}-3.750 * * * \\
(0.426)\end{array}$ \\
\hline $\begin{array}{l}\text { Observations } \\
\text { Number of groups }\end{array}$ & 71,613 & $\begin{array}{l}66,724 \\
20\end{array}$ & $\begin{array}{c}71,613 \\
21\end{array}$ & 71,613 & $\begin{array}{c}66,724 \\
20\end{array}$ & $\begin{array}{c}71,613 \\
21\end{array}$ \\
\hline 2009 & Duty I & Duty II & Duty III & Engaged I & Engaged II & Engaged III \\
\hline \multicolumn{7}{|l|}{ Individual level } \\
\hline Female & $\begin{array}{c}0.184 * * * \\
(0.023)\end{array}$ & $\begin{array}{c}0.196 * * * \\
(0.019)\end{array}$ & $\begin{array}{c}0.204 * * * \\
(0.019)\end{array}$ & $\begin{array}{c}0.582 * * * \\
(0.025)\end{array}$ & $\begin{array}{c}0.570 * * * \\
(0.023)\end{array}$ & $\begin{array}{c}0.564 * * * \\
(0.022)\end{array}$ \\
\hline \multicolumn{7}{|l|}{ SES proxy ${ }^{\mathrm{a}}$} \\
\hline 101-200 books & $\begin{array}{c}0.298 * * * \\
(0.029)\end{array}$ & $\begin{array}{c}0.057 * * \\
(0.025)\end{array}$ & $\begin{array}{c}0.052 * * \\
(0.025)\end{array}$ & $\begin{array}{l}-0.026 \\
(0.032)\end{array}$ & $\begin{array}{c}0.209 * * * \\
(0.029)\end{array}$ & $\begin{array}{c}0.205^{* * *} * \\
(0.029)\end{array}$ \\
\hline 201 books+ & $\begin{array}{c}0.254 * * * \\
(0.029)\end{array}$ & $\begin{array}{l}-0.049^{*} \\
(0.025)\end{array}$ & $\begin{array}{c}-0.055^{* *} \\
(0.025)\end{array}$ & $\begin{array}{c}-0.245 * * * \\
(0.032)\end{array}$ & $\begin{array}{c}0.098 * * * \\
(0.030)\end{array}$ & $\begin{array}{c}0.085 * * * \\
(0.029)\end{array}$ \\
\hline \multicolumn{7}{|l|}{ Country level } \\
\hline $\begin{array}{l}\text { Democracy } \\
\text { (years stable) }\end{array}$ & & $\begin{array}{c}0.024 * * \\
(0.011)\end{array}$ & & & $\begin{array}{l}-0.017 * \\
(0.010)\end{array}$ & \\
\hline GDP per capita & & & $\begin{array}{c}0.003^{* *} \\
(0.001)\end{array}$ & & & $\begin{array}{l}-0.002 * \\
(0.001)\end{array}$ \\
\hline Constant & $\begin{array}{c}-4.013 * * * \\
(0.018)\end{array}$ & $\begin{array}{c}-3.944 * * * \\
(0.330)\end{array}$ & $\begin{array}{c}-3.896 * * * \\
(0.321)\end{array}$ & $\begin{array}{c}-2.386 * * * \\
(0.020)\end{array}$ & $\begin{array}{c}-2.537 * * * \\
(0.315)\end{array}$ & $\begin{array}{c}-2.597 * * * \\
(0.307)\end{array}$ \\
\hline Observations & 73,890 & 71,111 & 73,890 & 73,890 & 71,111 & 73,890 \\
\hline Number of groups & & 20 & 21 & & 20 & 21 \\
\hline
\end{tabular}


Figure 1. Citizenship Norms in 1999, Highlighting 'Engaged' and 'Duty-based'

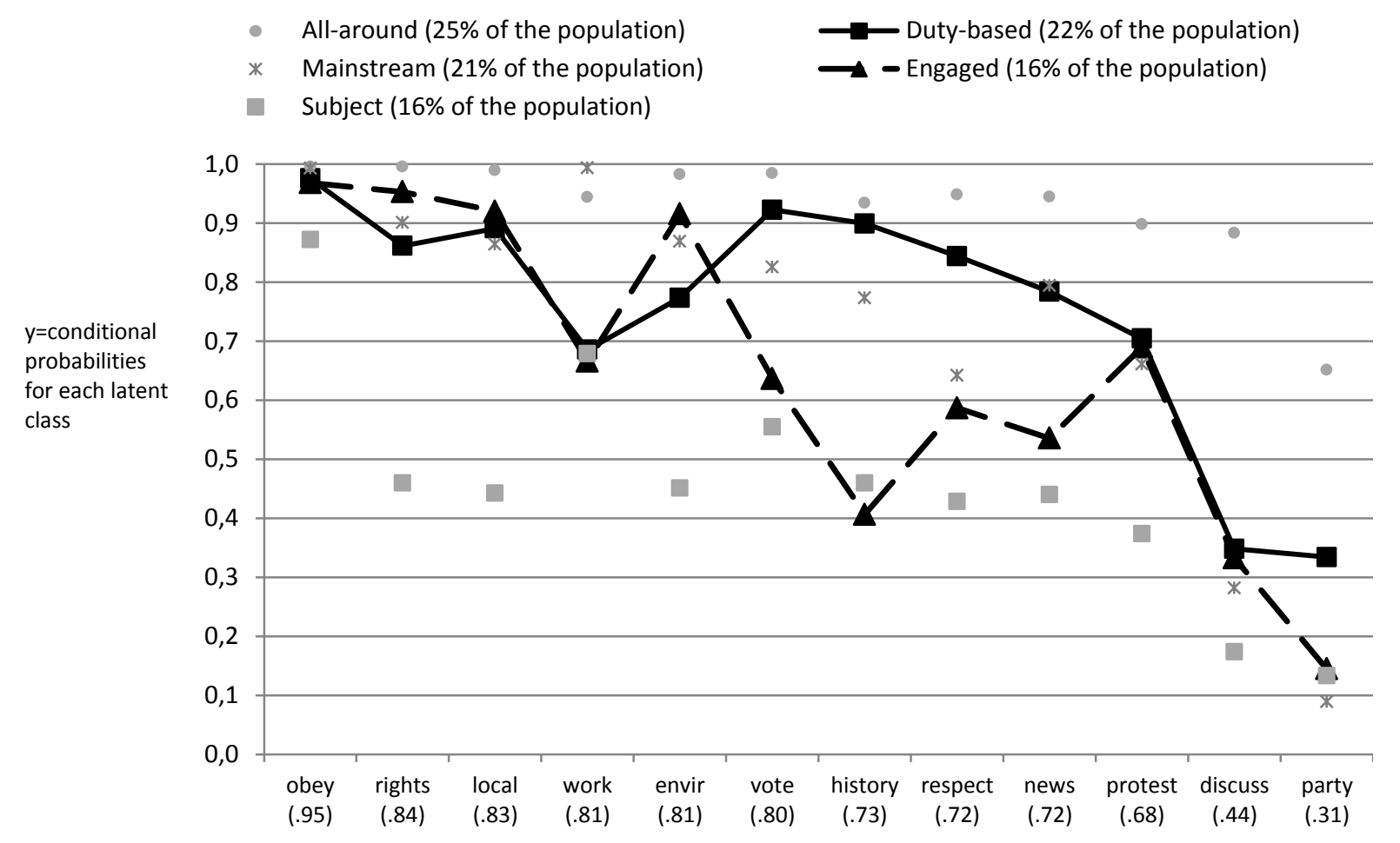

x=indicators included in the LCA, ordered by descending means in the Cived 1999 sample population (means noted in parentheses)

Source: Cived 1999. 
Figure 2. Citizenship Norms in 2009, Highlighting 'Engaged' and 'Duty-based'

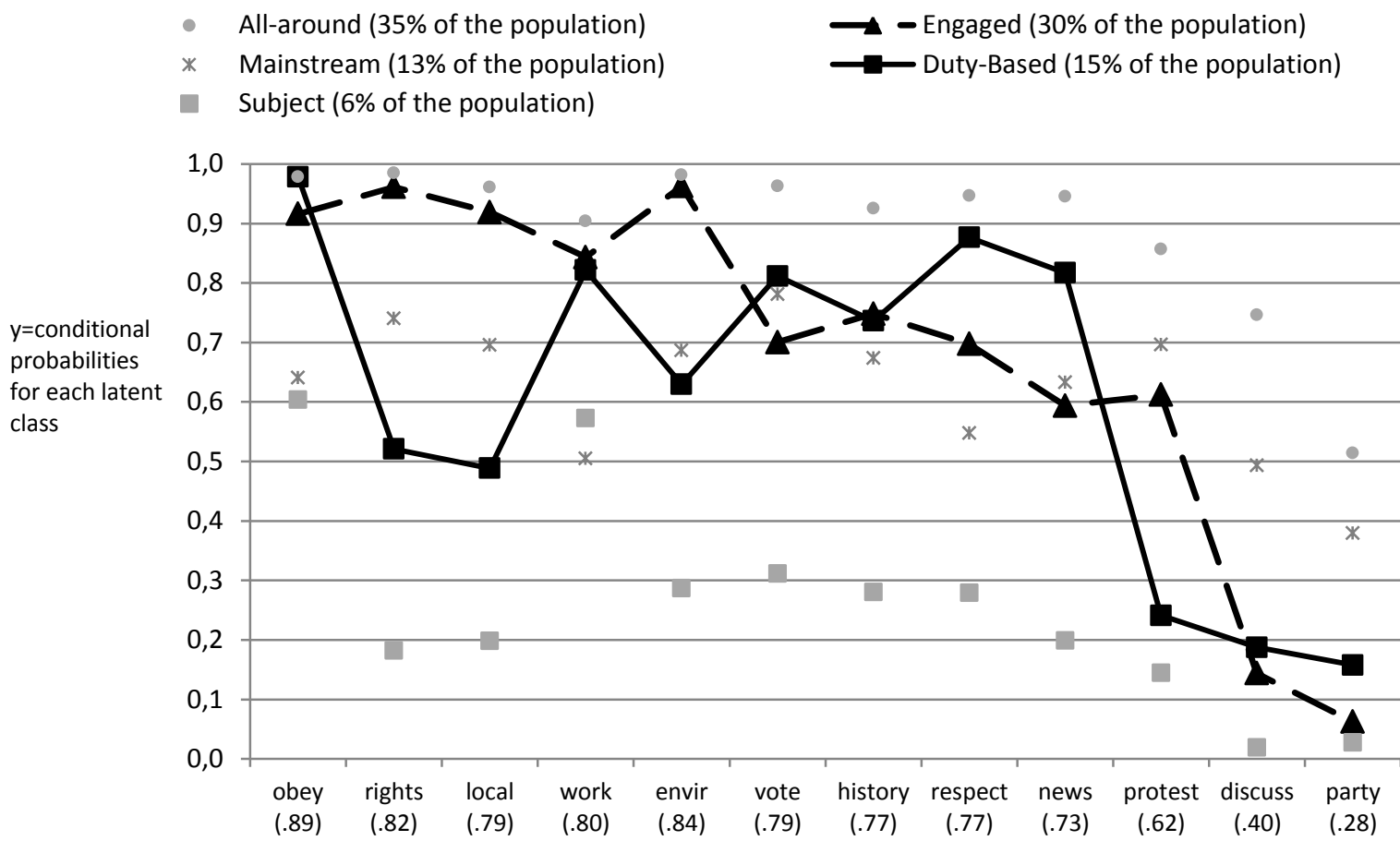

$x=$ indicators ordered by descending means in the CivEd sample population; ICCS 2009 means noted in parentheses

Source: ICCS 2009. 
Figure 3. Comparing the 'Engaged' Citizenship Norm in 1999 and 2009

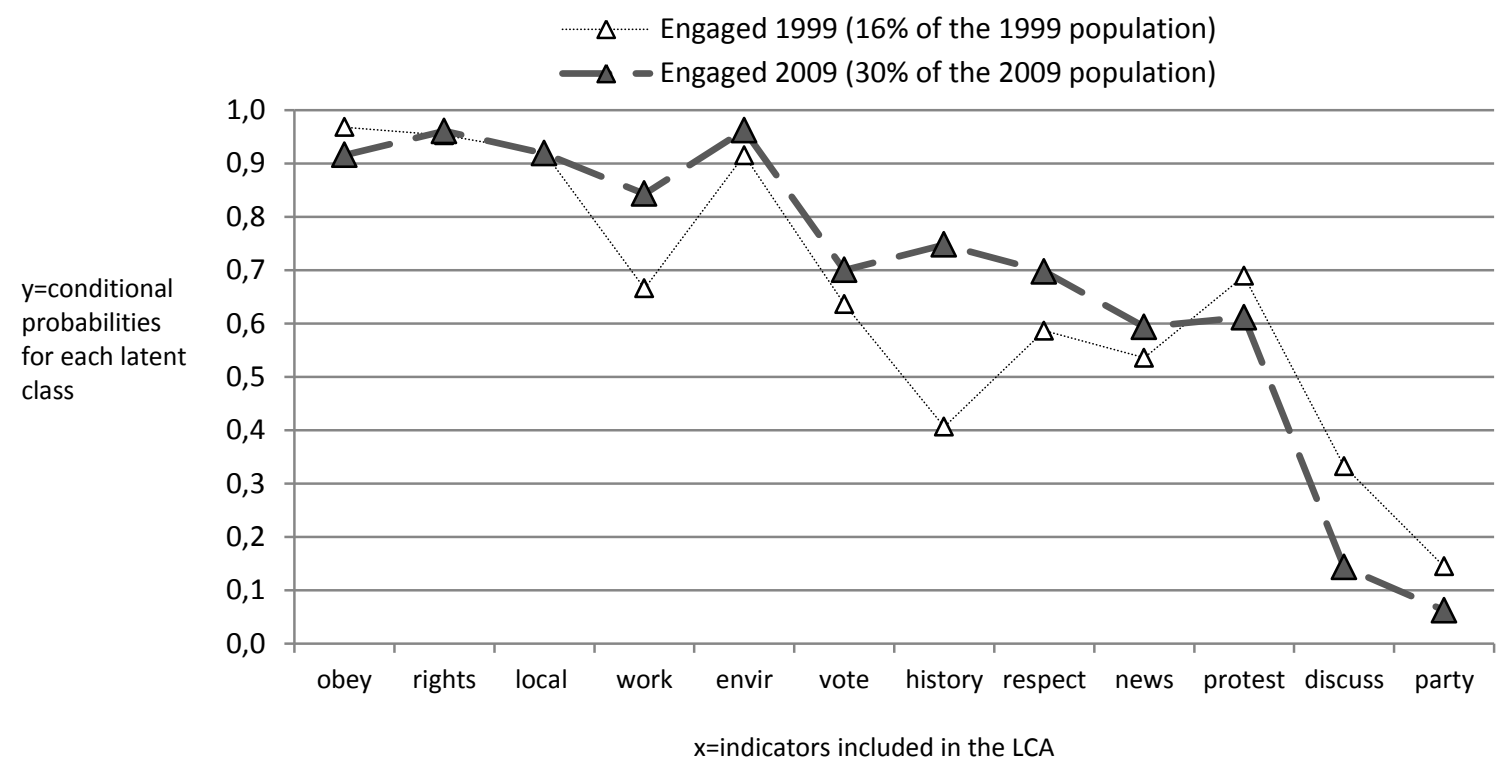

Sources: Cived 1999 and ICCS 2009. 
Figure 4. Comparing the 'Duty-based' Citizenship Norm in 1999 and 2009

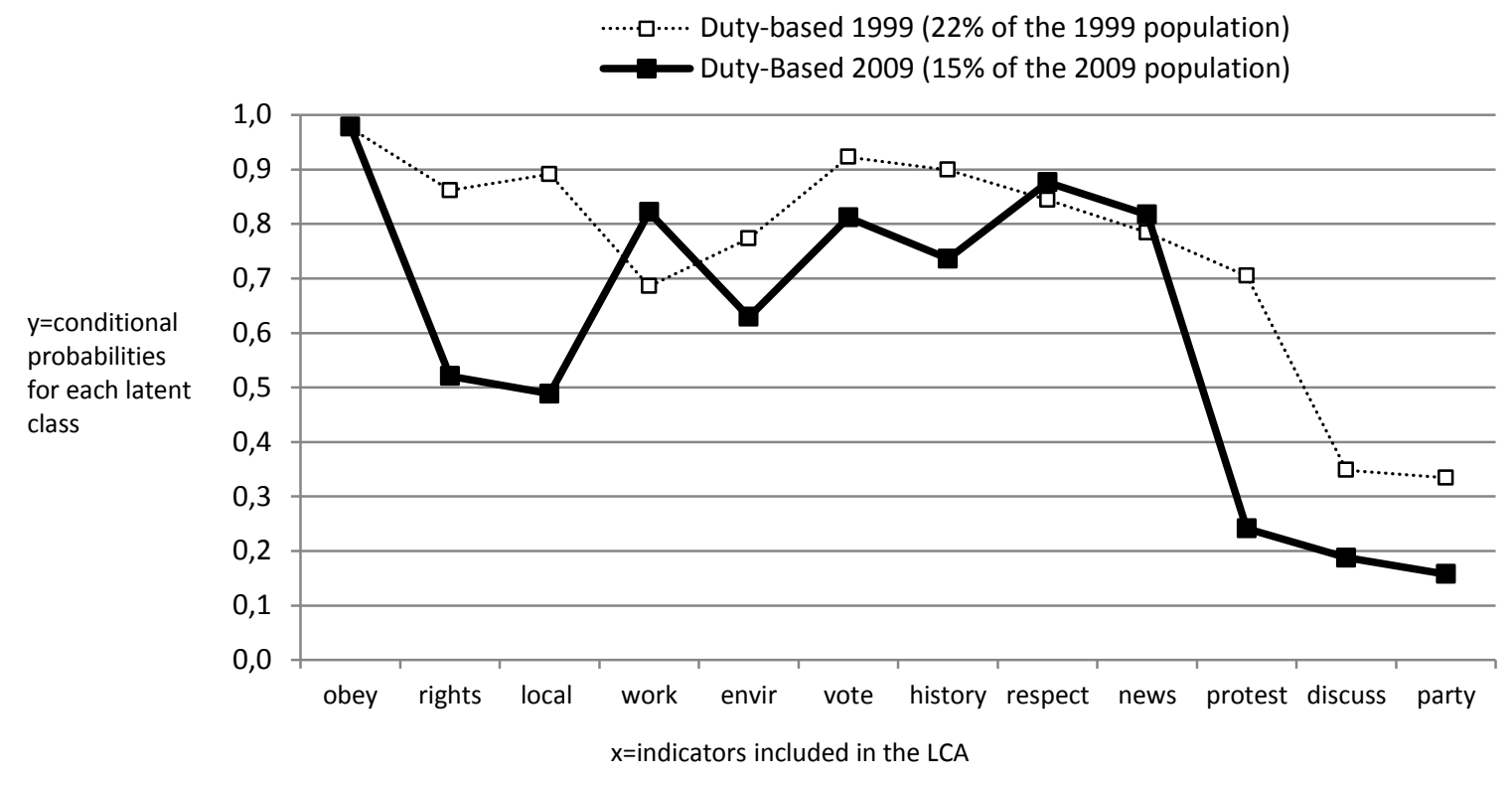

Sources: Cived 1999 and ICCS 2009. 
Figure 5. Distribution of Citizenship Norms, 1999 and 2009

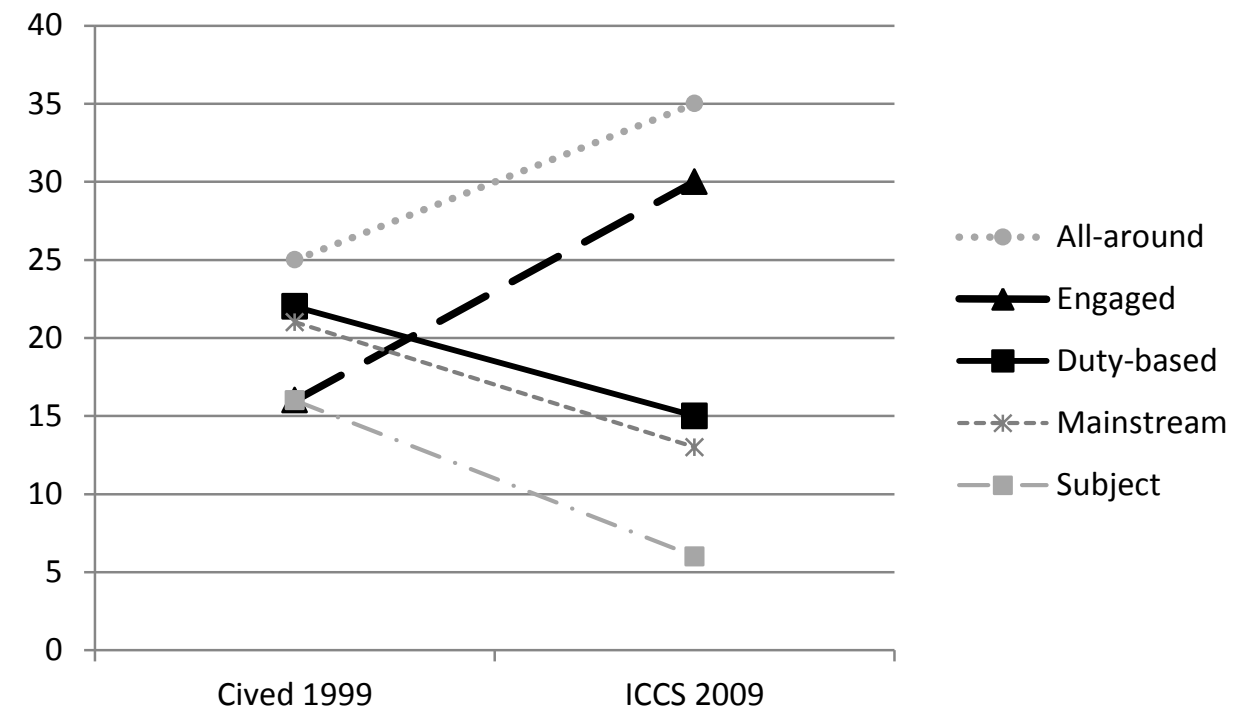

Sources: Cived 1999 and ICCS 2009. 


\section{Appendix}

Table A1. Distribution of Citizenship Norms According to Country, 1999

\begin{tabular}{lccccc}
\hline & $\begin{array}{c}\text { All-around } \\
(25 \%)\end{array}$ & $\begin{array}{c}\text { Duty-based } \\
(22 \%)\end{array}$ & $\begin{array}{c}\text { Mainstream } \\
(21 \%)\end{array}$ & $\begin{array}{c}\text { Subject } \\
(16 \%)\end{array}$ & $\begin{array}{c}\text { Engaged } \\
(16 \%)\end{array}$ \\
\hline Bulgaria & 0.31 & 0.13 & 0.26 & 0.25 & 0.05 \\
Switzerland & 0.14 & 0.30 & 0.05 & 0.23 & 0.29 \\
Chile & 0.26 & 0.53 & 0.14 & 0.07 & 0.00 \\
Columbia & 0.49 & 0.28 & 0.00 & 0.02 & 0.20 \\
Cyprus & 0.42 & 0.55 & 0.00 & 0.03 & 0.00 \\
Czech Republic & 0.07 & 0.05 & 0.40 & 0.22 & 0.26 \\
Denmark & 0.08 & 0.08 & 0.00 & 0.23 & 0.61 \\
England & 0.14 & 0.00 & 0.26 & 0.31 & 0.29 \\
Estonia & 0.06 & 0.13 & 0.41 & 0.30 & 0.10 \\
Finland & 0.06 & 0.00 & 0.51 & 0.40 & 0.03 \\
Greece & 0.51 & 0.37 & 0.03 & 0.03 & 0.05 \\
Hong Kong & 0.35 & 0.07 & 0.33 & 0.21 & 0.04 \\
Italy & 0.27 & 0.19 & 0.25 & 0.12 & 0.17 \\
Lithuania & 0.34 & 0.34 & 0.08 & 0.11 & 0.12 \\
Latvia & 0.14 & 0.24 & 0.27 & 0.25 & 0.09 \\
Norway & 0.16 & 0.00 & 0.21 & 0.10 & 0.52 \\
Poland & 0.37 & 0.52 & 0.02 & 0.09 & 0.00 \\
Russia & 0.11 & 0.07 & 0.53 & 0.21 & 0.09 \\
Slovak Republic & 0.29 & 0.00 & 0.61 & 0.06 & 0.04 \\
Slovenia & 0.15 & 0.41 & 0.02 & 0.26 & 0.16 \\
Sweden & 0.19 & 0.08 & 0.18 & 0.23 & 0.32 \\
\hline
\end{tabular}

Source: Cived 1999. Note: Entries are the proportion of respondents estimated to belong to a latent class as identified by LCA. 
Table A2. Distribution of Citizenship Norms According to Country 2009

\begin{tabular}{lccccc}
\hline & $\begin{array}{c}\text { All-around } \\
(35 \%)\end{array}$ & $\begin{array}{c}\text { Duty-Based } \\
(15 \%)\end{array}$ & $\begin{array}{c}\text { Mainstream } \\
(13 \%)\end{array}$ & $\begin{array}{c}\text { Subject } \\
(6 \%)\end{array}$ & $\begin{array}{c}\text { Engaged } \\
(30 \%)\end{array}$ \\
\hline Bulgaria & 0.28 & 0.02 & 0.08 & 0.05 & 0.58 \\
Switzerland & 0.23 & 0.33 & 0.20 & 0.09 & 0.15 \\
Chile & 0.36 & 0.06 & 0.07 & 0.04 & 0.47 \\
Columbia & 0.39 & 0.02 & 0.06 & 0.01 & 0.51 \\
Cyprus & 0.50 & 0.05 & 0.31 & 0.05 & 0.08 \\
Czech Republic & 0.18 & 0.09 & 0.06 & 0.12 & 0.55 \\
Denmark & 0.20 & 0.52 & 0.03 & 0.08 & 0.16 \\
England & 0.41 & 0.22 & 0.08 & 0.08 & 0.21 \\
Estonia & 0.21 & 0.19 & 0.10 & 0.06 & 0.44 \\
Finland & 0.18 & 0.25 & 0.02 & 0.13 & 0.42 \\
Greece & 0.35 & 0.01 & 0.35 & 0.03 & 0.26 \\
Hong Kong & 0.58 & 0.24 & 0.02 & 0.04 & 0.12 \\
Italy & 0.68 & 0.18 & 0.06 & 0.01 & 0.07 \\
Lithuania & 0.38 & 0.22 & 0.18 & 0.04 & 0.18 \\
Latvia & 0.36 & 0.08 & 0.42 & 0.04 & 0.09 \\
Norway & 0.56 & 0.10 & 0.09 & 0.04 & 0.21 \\
Poland & 0.42 & 0.12 & 0.24 & 0.05 & 0.17 \\
Russia & 0.52 & 0.16 & 0.14 & 0.04 & 0.15 \\
Slovak Republic & 0.17 & 0.09 & 0.17 & 0.10 & 0.46 \\
Slovenia & 0.23 & 0.10 & 0.16 & 0.11 & 0.40 \\
Sweden & 0.26 & 0.14 & 0.08 & 0.14 & 0.38 \\
\hline
\end{tabular}

Source: ICCS 2009. Note: Entries are the proportion of respondents estimated to belong to a latent class as identified by LCA. 
Table A3. Descriptive Statistics of Variables in Multilevel Regression Analyses

\begin{tabular}{|c|c|c|c|c|c|}
\hline 2009 & $\mathrm{~N}$ & Mean & Std. Dev. & Min. & Max. \\
\hline Female & 74308 & 0.51 & 0.50 & 0 & 1 \\
\hline SES proxy $^{\mathrm{a}}$ & 74173 & 1.61 & 0.80 & 1 & 3 \\
\hline Democracy $(\text { years })^{b}$ & 72118 & 40.92 & 30.65 & 0 & 90 \\
\hline GDP per capita $^{c}$ & 75020 & 313.87 & 241.40 & 51.74 & 1025.26 \\
\hline 1999 & $\mathrm{~N}$ & Mean & Std. Dev. & Min. & Max. \\
\hline Female & 71948 & 0.52 & 0.50 & 0 & 1 \\
\hline SES proxy & 71812 & 1.67 & 0.84 & 1 & 3 \\
\hline Democracy (years) & 67546 & 34.13 & 29.67 & 0 & 82 \\
\hline GDP per capita & 72543 & 143.92 & 120.40 & 16.23 & 393.04 \\
\hline
\end{tabular}

Source: Cived 1999 and ICCS 2009. Notes:

a. SES proxy is the self-reported number of books at home that includes the following categories: (1) 0-100 books (2) 101-200 books (3) 201+ books.

b. Democracy (years): based on the POLITY IV 2011 dataset for 1998 and 2008, and includes the total number of years that the country scored 8 or higher on the 10-point democracy index (Marshall, Gurr, and Jaggers, 2011).

c. Based on the International Monetary Fund's World Economic Outlook Database, annual data for 1998 and 2008 (International Monetary Fund, 2013). 